\title{
Cnoty lekarza w polskiej lekarskiej myśli filozoficzno- -moralnej w XVIII i XIX wieku
}

Słowa kluczowe: lekarz, cnoty, filozofia moralna, etyka lekarska

\section{Wstęp}

W XVIII w. nauka obyczajowa (nauka moralna, filozofia moralna) w Polsce osiągnęła najpełniejszy rozwój. Obejmowała wiedzę teoretyczną o cnotach i wadach ludzkiego charakteru, była źródłem formułowania katalogu powinności obywatelskich, stanowiła podstawe filozofii prawa, a nawet rodzącej się estetyki. Przybierała również postać poradników moralnych dla różnych stanów i urzędów, kadetów, kobiet, młodzieży i dzieci, synów i córek. Była nadto przedmiotem nauczania w szkołach wydziałowych i ponadwydziałowych zgodnie z programem nauczania Komisji Edukacji Narodowej. Jej źródła teoretyczne tkwiły w rzymskim stoicyzmie, w myśli Cycerona, Seneki i Marka Aureliusza.

Niezbędność nauki obyczajowej uzasadniał Hugo Kołłątaj następująco: „Dobra nauka moralna jest nieuchronnie potrzebna dla każdego, bo wszystkie sprawy nasze moralne są nieoddzielnym owocem nasze-

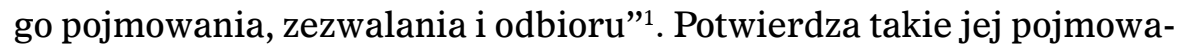
nie Ludwik Koncewicz, pisząc: „Nauka pokazująca człowiekowi jego powinności i podająca środki, jak ma one wypełniać, nazywa się nauką

${ }^{1}$ H. Kołłątaj, Korrespondecya listowna z Tadeuszem Czackim, Kraków 1845, s. 99. 
moralną. Ta z pomiędzy wszystkich nauk wszechstronnie nas kształcących, jako wprost, nauczająca nas cnoty, a przez cnotę prowadząca do szczęścia, jest bezwątpienia najważniejszą i najpotrzebniejszą nauką”2. Podobnie uzasadnia jej ważność Stanisław Kostka Potocki: „nie masz potrzebniejszej nad moralność nauki, co nas cnotliwemi bydź uczy”3 oraz Andrzej Markiewicz: „Nauka obyczajowa czyli moralna (ta to wiadomość prawideł wykreślonych odwiecznie dla wolnej woli człowieka z zasadzonych na jego przyrodzeniu, potrzebach i miłości jestestwa swego) jest naszą nauką obowiązków, jakie ludziom dążącym z natury do celu zachowania się i szczęśliwości przystoją: czyli jest nauką uczącą żyć dobrze""

Jej uprawianie polegało na katalogowaniu cnót i wad moralnych, u podstaw mające koncepcję cnót kardynalnych, która została „przekazana średniowieczu łacińskiemu przede wszystkim za pośrednictwem tradycji stoickiej (Seneka), stała się u ówczesnych autorów typowym locus communis"s. Refleksja nad cnotami i wadami jako filozofia praktyczna, swoista dietetyka obyczajów, snuje się wyraziście już od Mikołaja Reja (sprawiedliwość, roztropność, prawdomówność, stałość umysłu, uczynność) i Jana Kochanowskiego (mądrość, sprawiedliwość, wielkości umysłu, skromności w mowie i uczynkach), aż po przedstawicieli polskiej myśli politycznej (Ł. Górnicki, A. Frycz Modrzewski, K. Piekarski) - jako nauka, „która uczy dobrze żyć, która nie tylko cnotliwie, ale i szczęśliwie ludzi rodzi, która każdemu człowiekowi powinność jego w każdej sprawie jego pewny i prawdziwy cel pokazuje"6, pisał Szymon Starowolski. Uprawiali ją Stanisław Herakliusz Lubomirski, Józef Lomkau, Ignacy Krasicki, Franciszek Bohomolec, Franciszek Karpiński, Stanisław Kostka Potocki, Grzegorz Piramowicz, Marcin Nikuta, Andrzej Markiewicz, Józef Sołtykiewicz, Ignacy Skarbek Kiełczewski, Hugo Kołłątaj, Hieronim Stoynowski, jak i Franciszek Ksawery Dmochowski, dla którego pierwszą cnotą i główną jest sprawiedliwość, bo na niej „wszystkie inne cnoty się za-

${ }^{2}$ L. Koncewicz, Nauka moralna o powinnościach człowieka względem siebie samego ułożona dla użytku klass wyższych szkót wojewódzkich, Warszawa 1830, s. 2.

${ }^{3}$ S.K. Potocki, Pochwała Grzegorza Piramowicza, miana w Zgromadzeniu Przyjaciót Nauk, Warszawa 1802, s. 45.

${ }^{4}$ A. Markiewicz, Nauka obyczaiowa o obrzydzeniu występków, wad i przesadów a zamiłowaniu prawdy, cnoty i przymiotów towarzyskich do uksztatcenia młodzieży na dobrych ludzi, obywatelów i urzędników stosowna, Kraków 1810, s. 3.

${ }^{5}$ S. Swieżawski, U źródeł nowożytnej etyki. Filozofia moralna w Europie XV wieku, Kraków 1987, s. 92.

${ }^{6}$ S. Starowolski, Poprawa Niektórych obyczaiow Polskich potocznych, Kraków 1625, s. 10. 
sadzają”. Drugą zaś cnotą, według tłumacza „Iliady”, jest ludzkość, czyli zdolność do dobrego życzenia ludziom i służenia im pomocą: „Powinienem bydź dla każdego człowieka życzliwym i dobrym, bo

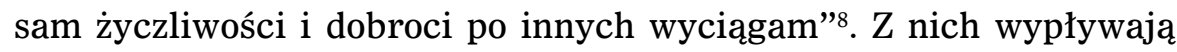
cnoty pozostałe i przymioty moralne, takie jak czułość, litość, dobroczynność, prawdomówność, cierpliwość i wyrozumiałość, łagodność i grzeczność. To potężna narracja, również teoretyczna, która nie pozostawia żadnego obszaru ludzkiego postępowania bez oceny moralnej i bez wskazania moralnego. Jest ona, nauka obyczajowa, nauka moralna, tą przestrzenią refleksji nad moralnością, w której mieszczą się pierwsze lekarskie katalogi cnót moralnych i w której odnajdują swoją treść i uzasadnienia. Nie była tym źródłem filozofia scholastyczna, albowiem, jak pisał Michał Wiszniewski, ,szlachta, a szczególniej panowie uczyć się filozofii scholastycznej za rzecz niegodną swego urodzenia poczytywali" .

\section{Pierwsze postaci myśli etyczno-lekarskiej}

Treści nauki obyczajowej odzwierciedliły się w lekarskiej refleksji, choć do XVIII w. nie istniała taka potrzeba, aby rozważania etyczne nad postępowaniem lekarskim uzyskały jakąkolwiek przedmiotową samodzielność. Tłumaczy to poniekąd Józef Bieliński, pisząc: „Co się tyczy etyki lekarskiej, to chociaż nie układano jej w pewne paragrafy, jak to w dzisiejszych czasach jest na porządku dziennym, jednakże przenikała ona wszystkich i była kierowniczką w dalszem życiu pojedynczego lekarza"10, który nie uczył się jej z książek, lecz z przykładu, jaki dawali starsi koledzy w zawodzie. Przykład wszelako w drugiej połowie XIX w. już nie wystarczał, gdy nastąpił postęp w terapii i gdy zmieniły się instytucjonalne, edukacyjne i prawne ramy praktyki lekarskiej.

Dotąd etyczna myśl nad postępowaniem lekarskim przybierała skromną postać - jako polityka lekarza, czyli namysł nad godziwym i rozsądnym postępowaniem, obliczonym na cel, którym jest - jak pisał Christoph Hufeland - utrzymanie życia, przywrócenie zdrowia i łagodzenie cierpienia ${ }^{11}$. Polityka ta obejmowała prawidła lekarskiego

${ }^{7}$ F.K. Dmochowski, O cnotach towarzyskich, [w:] F.K. Dmochowski, Pisma rozmaite, t. 2, Warszawa 1826, s. 123.

${ }^{8}$ Tamże, s. 126.

${ }^{9}$ M. Wiszniewski, Historya literatury polskiej, t. 3, Kraków 1841, s. 188.

${ }^{10} \mathrm{~J}$. Bieliński, Stan nauk lekarskich za czasów Akademii Medyko-Chirurgicznej Wileńskiej, Warszawa 1888, s. 379.

${ }^{11}$ C.W. Hufeland, Die Verhältnisse des Arztes, „Neues Journal der praktische Arzneykunde und Wundarztneykunst" 1806 , t. 16, s. 5 . 
działania w odniesieniu do chorego, społeczeństwa i innych lekarzy. Do niej odwołuje się jeszcze Ludwik Bierkowski, starając się wyjaśnić powód, dla którego czynione są sztuce lekarskiej wyrzuty lub wypowiadane złorzeczenia: dzieje się tak wtedy, gdy lekarz „niezachowuje częstokroć należytej szczytnemu powołaniu swojemu odpowiedniej powagi, ale co gorsza nie przestrzega ściśle tej tak zwanej polityki lekarskiej"12. W tym duchu Franciszek Ksawery Ryszkowski rozpisuje powinności lekarza w Stanie człowieka zdrowego naturalnym (1786). Określa on cel działań lekarskich jako ochronę i ratowanie zdrowia, które są jedynym dobrem w życiu doczesnym przynoszącym człowiekowi szczęście. Ci jednak, którzy pragną poświęcić się lekarskiemu zawodowi, uczynić to powinni z rozmysłem, uwzględniając nade wszystko, że „najszacowniejszego bowiem skarbu swego, to jest zdrowia i życia chory powierza lekarzowi: ten jeśliby pobłądził, pobłądziłby z nieodzyskaną dla chorego szkodą"13. A że najczęstszą przyczyną błędnego postępowania lekarza jest zwykłe niedbalstwo, dlatego - postuluje Ryszkowski - nie należy dopuszczać do stanu lekarskiego „tych, którzy sposobnego dowcipu, wielkiej pilności, roztropności i dobrych nie byli obyczajów"14. Polityka lekarza polega zatem na chronieniu siebie, wystrzeganiu się nieobyczajności i przestrzeganiu prawideł. Dlatego lekarz nie powinien choćby, pomimo tego, że zapłata jest mu należna, targować się o nią, a w szczególności wtedy, gdy pacjent zapadł na niebezpieczną chorobę lub pogrążony jest w boleściach - po to, aby za „łakomego nie był poczytanym”15. I dosadnie wyłuszcza Ryszkowski formułowane tu prawidło postępowania, pisząc: „chronić się ma każdy Lekarz, by zysku więcej, jakby się godziło nie pragnął, i sztuki swej, która coś ma w sobie Bozkiego ludziom nie przedawał"16. Nadto wystrzegać się powinien pośpiechu, jak również pokusy obmowy swoich kolegów w sztuce lekarskiej. Powinien zaś „uczciwie żyć, nikogo nie obrażać, każdemu co jego jest oddawadź"17. Na uczciwości bowiem, szacunku i sprawiedliwości opiera się moralne postępowanie lekarza.

Bodaj pierwszą w Polsce, wnikliwą i jednocześnie pełną wrażliwości deklaracją aksjologiczną, której przedmiotem stały się powinności moralne lekarza, była Dyssertacya o szlachetności chirurgii Rafała

\footnotetext{
${ }^{12}$ L. Bierkowski, Wstęp do anatomii ciała ludzkiego, Kraków 1850, s. XLVII.

${ }^{13}$ F.K. Ryszkowski, Stan człowieka zdrowego naturalny, Kraków 1808, s. 201.

14 Tamże, s. 202.

15 Tamże, s. 210.

16 Tamże, s. 212.

17 Tamże, s. 235.
} 
Józefa Czerwiakowskiego. Wygłoszona w obliczu majestatu króla Stanisława Augusta na posiedzeniu Szkoły Głównej Koronnej w 1791 r. w intencji miała nie tylko załagodzić spory między chirurgami a medykami, ukazać chirurgię jako część medycyny niezwykle potrzebną medykom, ale także dookreślić edukacyjne wymiary kształcenia medycznego. $\mathrm{W}$ dysertacji tej Czerwiakowski zamieścił jedną $\mathrm{z}$ najpiękniejszych sentencji, która, jako twierdzenie, cały rozwój etyki medycznej ma za swój komentarz: „Chirurgia, owa to istotna Część Medycyny podług swego Greckiego pierwiastku znaczy Rękodziałanie; ale Ręko-działanie nader Szlachetne, bo za cel mające samego Człowieka i jego nie oszacowane dobro, a to jest: Zdrowie" ${ }^{18}$. Jest ona bowiem działaniem wywodzącym się ze szlachetnych pobudek, uszlachetniającym tym samym sprawcę, a z przymiotnikiem „nader” - wynoszącym się ponad zwykłe ludzkie moralne zobowiązania, bo ukierunkowanym na cel dobroczynny, którym jest ochrona najcenniejszego dobra człowieka.

Spełniając powołanie, lekarz nie tylko usposobiony ma być do zdobycia wiedzy i umiejętności medycznych, ale nadto „powinien on jeszcze starać się usilnie, o uformowanie swojego serca i obyczajów, równie mu do tego celu, jak i same wiadomości potrzebnych. Potrzeba więc, aby miał serce przeniknione miłością Ludzi, skąd rodzi się ów tak wielki, a w Towarzystwie Ludzkiem każdej osobistej zasłudze, zaletę nadający przymiot, bydź użytecznym bez wyjątku każdemu; potrzeba aby wykorzenił zupełnie z serca swojego, już to ową srogość, której jest skutkiem nieznośne obchodzenie się z chorym, już ową zuchwałą dumę zbytniego o sobie rozumienia z pogardy innych, której ofiary częstokroć pada cierpiący; już owe podłe i nie nasycone łakomstwo, ubiegające się tylko za blaskiem Złota, a głuche na skwierk nieszczęśliwego ubóstwa. Te to razem zebrane przymioty z strony oświecenia rozumu, i uformowania serca, stanowią dopiero podług mego przekonania prawdziwie użytecznego Chirurga, jakiego dla pomocy i ulgi cierpiącej Ludzkości, Krajowi życzyć należy"19.

Czerwiakowski wyposaża chirurga w te przymioty moralne, które są niezbędne do sprawowania medycznej opieki nad chorym, do których należą: ludzkość wraz z uczynnością (dobroczynnością), zdolność do okazywania współczucia (litość), cierpliwość, grzeczność (uszanowanie, obyczajność) i łagodność. Wierny swojemu powołaniu (posłannictwu), jako pocieszyciel bolejącej ludzkości i kierujący

${ }^{18}$ R.J. Czerwiakowski, Dyssertacya o szlachetności i potrzebie Chirurgii w Pożyciu Ludzkiem, W Woysku, Przy Połogach i w Nauce Lekarskiey, Warszawa 1791, s. 8.

${ }^{19}$ Tamże, s. 5-6. 
się cnotami, będzie mógł właściwie uprawiać sztukę leczenia: „Powszechne bowiem Hasło jego Sztuki piętnuje zwyczajnie w sercu jego to czucie, że wszystko, co cierpi, ma prawo do jego litości, i że podobnemu sobie Jestestwu w przypadkach bólu i nieszczęścia winien jest pomoc i uszanowanie. Na tem to fundamencie gruntuje się ów gatunek szlachetnej Chirurga, w Towarzystwie Ludzkiem zasługi, iż częstokroć nie tylko nie wymaga wdzięczności, za najszczerszą uczynność i najtrudniejszą pracę; ale zdrowia samego i honoru uszczerbek bolejących ratunkowi z heroiczną poświęca cierpliwością” ${ }^{20}$. Dzięki temu chirurg zdolny jest do tego, aby „kojącemi słowy, uśmierzać trwożliwość umysłu i uspokajać bojaźń dla zbliżającej się bolesnej operacji, aby się Chory nie lękał; jak jest powinnością umieć ulżyć, cierpienie, i znieść zręcznie i skutecznie dolegliwości przyczynę"21.

Prócz tych wielu cnót chirurga powinna cechować przytomność umysłu oraz sprawność ręki, a nade wszystko brak wad pospolitych, do których Czerwiakowski zalicza nieczułość (nieludzkość), pychę, próżność i pazerność. Wyraża jednocześnie to głębokie przekonanie, że „prawdziwy talent wiele traci ze swej prawdziwej wartości, gdy od obyczajów zalety nie ma”; że chirurg często utalentowany „nie zastanawia się nad tem, jak wiele nieczułość serca, grube obyczaje, w samem nawet dobrze-czynieniu nieszczęśliwemu człowiekowi powiększają przykrości”22. Winien on rządzić się prawidłami cnoty ${ }^{23}$, dzięki którym zdolny jest wtedy do uprawiania tej nauki, złączonej „z dobremi obyczajami, i potrzebnemi przymiotami serca" 24 . W pozostającej zaś w rękopisie pracy Nauka chirurgii uniwersalnej (1815) dodaje Czerwiakowski jeszcze cnotę miłości, stateczności, czułości, skromności, niechciwości i wstrzemięźliwości ${ }^{25}$, jednoznacznie deklarując: „Ten tylko może się śmiele puszczać za powołaniem chirurgicznym, kto czuje w sobie wyższą nad pospolitą miłość ku podobnym sobie, kto pała prawie żądzą bycia użytecznym swym bliźnim, kto zgoła być może bohaterem pominającym o sobie samym”26.

\footnotetext{
${ }^{20}$ Tamże, s. 31.

${ }^{21}$ Tamże, s. 40.

${ }^{22}$ Tamże, s. 7.

${ }^{23}$ Tamże, s. 31.

${ }^{24}$ Tamże, s. 39.

${ }^{25}$ J. Borówka, Polska etyka lekarska w ujęciu dziejowym. Studium filozoficzno-historyczne, Torun 2012, s. 290.

${ }^{26}$ Za: E. Grzelak, Co powinno cechować chirurga według R.J. Czerwiakowskiego, „Biuletyn Wojskowej Akademii Medycznej” 1963, nr IV, z. 3-4, s. 102.
} 
Nieczułość w postaci nieokazywania ludzkości, która to ludzkość w okresie oświecenia uchodzi za drugą po sprawiedliwości cnotę, jest jedną z głównych wad lekarza. Michał Anioł Bergonzoni, spolszczony lekarz z Bolonii, wykładowca szkoły chirurgicznej w Warszawie, w swojej dysertacji (z 1782 r.) odnajduje źródła nieczułości lekarzy w takich przywarach, do których należą również pomówienia i zazdrość. Pisze on „o bezwzględnych potwarzach i zazdrości samych między sobą Lekarzow, które częstokroć nędznym chorym śmierć przynoszą i stają się ohydą i wyszydzeniem tak sztuki, jak i sztuką bawiącego się"27. Jest to postępowanie sprzeczne z zadaniem lekarza, które polega na czynieniu honoru człowieczeństwu, czyli na odkrywaniu przyczyn chorób. Dzięki temu spełnia on swój obowiązek wobec społeczności: „Lekarz, który poświęciwszy się umiejętności chorób leczenia, włożył na siebie szczególny obowiązek bydź każdemu użytecznym"28.

O uzdolnieniach chirurga rozpisuje się w „Nauce chirurgii” (1806) Jakób Szymkiewicz. Według niego chirurg powinien mieć zamiłowanie do swojej wiedzy i praktyki, być zdrowym, spostrzegawczym, aby łatwo mógł zaobserwować (wypatrzeć lub wyczuć) objawy choroby, następnie winien być zręczny, silny, gibki, dwuręczny i zdolny do oceny praktycznej urządzeń chirurgicznych, a nadto „powinien bydź trafnym, dowcipnem, wielki rozum, dobrą i lokalną pamięć, jako teź rozsądek zdrowy posiadającym. Nakoniec: miłosierdzie, pilność, czynność, niechciwość, rezolutność są zdobiącemi cnotami Chirurga"29.

Ta współobecność przymiotów moralnych i usposobień fizycznych oraz intelektualnych jest trwałym wątkiem rozważań o uzdolnieniach nie tylko lekarza, ale także położnych. Ludwik Perzyna w Nauce położnej krótko zebranej wydanej w 1790 r. wylicza konieczne zalety moralne położnych: powinny one być „czułemi, litościwemi, ludzkiemi, cierpliwemi [...], mają być życia skromnego, poczciwego, honor kochającego, i bogobojne" 30 . A jeśli rzecz dotyczy lekarza, pisze w Lekarzu dla włościan (1792), powinien on być poczciwy, biegły, rozważny, rzetelny, stroniący od pychy, opiekuńczy i przyjacielski ${ }^{31}$, a także umiejętnie

${ }_{27}$ A. Bergonzoni, Lublin podług ustaw medyki uważany w jednej dyssertacyi, Lublin 1792, $₫$ II.

${ }^{28}$ Tamże, $§ X X X$.

${ }^{29}$ J. Szymkiewicz, Nauka chirurgii teoryczney i praktyczney, t. 1, Wilno 1806, s. 9.

${ }^{30}$ L. Perzyna, Nauka położna krótko zebrana. Cyrulikom położnym, iako też $i$ Babom, czyli Kobietom, przy rozwiazywaniu rodzacych Położnic stużacym dla wiadomości bardzo potrzebna, Kalisz 1790, s. 3.

31 L. Perzyna, Lekarz dla włościan czyli rada dla pospólstwa, w chorobach i dolegliwościach naszemu Kraiowi właściwych [...], Kalisz 1793, s. 322-327. 
obchodzący się z pacjentem, co bodaj wypełnia treść taktu lekarskiego: „Doktor honor kochający i sumienie mający, obcesowo sobie z pacjentem postępować nie może, by omyłce jakowej nie popadł"32.

\section{Katalogi cnót lekarza}

Pierwszy rejestr cnót lekarskich podał Wincenty Szczucki, autor Propedeutyki do nauk medycyny (1825), w której to propedeutyce wymienia konieczne przymioty serca, umysłu i ciała lekarza. Lekarzowi właściwe powinny być następujące władze umysłu: łatwość pojęcia, zdolność zastanawiania się, niezawodna pamięć, rozsądek rozumiany jako bezstronny osąd. Do usposobień fizycznych lekarza Szczucki zaliczał: czerstwe zdrowie, zmysł czucia (dotyku), mocny wzrok i dobry słuch oraz dobry węch. Cnoty moralne zaś - a powszechne to wtedy przekonanie - będące ozdobą człowieka, mają i lekarza zdobić, a wszelkie „wykroczenia moralności przeciwne, niechaj na zawsze będą od niego dalekiemi" ${ }^{33}$. Jest to wymaganie, które przypisane zostało tym, którzy uprawiają sztukę lekarską nie za sprawą tego, że medycyna - pisze Szczucki świadom nazbyt śmiałej swej wypowiedzi - jest bodaj najpierwszą i najbardziej użyteczną z wszelkich nauk, lecz dlatego właśnie - i tu Szczucki nie ma żadnej wątpliwości - „iż przedmiot, którym się ona trudni, ze wszystkich dóbr życia doczesnego, jest najszlachetniejszym i najdroższym" ${ }^{34}$. Dlatego, aby być lekarzem, należy mieć ku temu powołanie, które wymaga w sposób konieczny usposobienia moralnego polegającego na „bezinteressownej i niczem nieodmiennej chęci wypełnienia wszystkiego, cokolwiek ludziom cierpiącym przynieść może ulgę"35.

Propedeutyka do nauk medycyny to dzieło szczególne, ponieważ jest jedną z pierwszych (jeśli nie pierwszą) propedeutyk europejskich, w których podejmowana jest problematyka etyczna, a także dlatego, że jest twierdzi Władysław Szumowski - pracą lekarza, którego należy uważać „za poprzednika szkoły filozoficznej”36, polskiej szkoły filozofii medycyny. Szczególnie za sprawą jego Krótkiego zbioru zasad medycyny praktycznej, w którym formułowany jest postulat metodologiczny „doświadczalności rozumowej” (empyria rationalis): spełnia go to postępowanie w leczeniu chorych, które jest „,na pewnych oparte zasadach, i połączone

\footnotetext{
32 Tamże, s. 338.

${ }^{33}$ W. Szczucki, Propedeutyka do nauk medycyny, Warszawa 1825, s. 189-190.

${ }^{34}$ Tamże, s. 164.

35 Tamże, s. 165.

${ }^{36}$ W. Szumowski, Dwa kursa propedeutyki, „Krytyka Lekarska” 1907, nr 1(11).
} 
z trafnością tłomaczenia wydarzonych skutków" ${ }^{37}$. Ale i tutaj, w kontekście metod diagnostyki i terapii, Szczucki, podejmując problematykę efektywnego badania chorego, nie zapomina o etycznych aspektach postępowania lekarskiego, które musi przebiegać z roztropnością i taktem: towarzyszyć badaniom powinna „łagodność i przyzwoita skromność”38; „Nie należy w niczym obrażać przyzwoitej wstydliwości, a zwłaszcza osób niewinnych" ${ }^{39}$. Podobnie jak August Wolff, który w Rysie sztuki leczenia postępowanie lekarza warunkuje umiejętnym zadawaniem choremu pytań, implicite odwołując się do cierpliwości okazywanej chorym, a w którą lekarz musi się uzbroić przy rozwlekłości wypowiedzi u hipochondryków lub histeryków albo przy milczeniu melancholików, osób zniedołężnianych bądź wstydliwych zanadto: „W tym razie tkliwe i rozsądne przełożenie ze strony Lekarza, wzbudzając $\mathrm{w}$ chorym zaufanie, zdolnem jest częstokroć do ośmielenia go, i otworzenia mu ust" ${ }^{40}$. Wolff zwraca ponadto uwage na konieczny warunek leczenia, jakim jest emocjonalny spokój chorego: „wzgląd mieć należy na namiętności, którym chory podlega. Gwałtowna namiętność $\mathrm{w}$ żadnej chorobie pożyteczną bydź nie może, czy takowa do ukontentowania lub smutku prowadzi. Ponieważ nigdy przewidzieć nie można do jakiego stopnia zdoła namiętność unieść człowieka, dla tego wypada w ogólności usunąć to wszystko, coby jakową wzbudzić mogło - Namiętności mogą wprawdzie bydź użyte jako środki leczące, jednakże te policzone są dotąd pomiędzy trudne zagadnienia medyczne; i wymagają głębokiej znajomości ludzi”"

W Propedeutyce zaletom etycznym lekarza poświęca Szczucki rozdział zatytułowany $O$ przymiotach moralnych, jako istotnym warunku dla ucznia Medycyny. Podkreśla w nim, że wiedza nie czyni kogokolwiek zdolnym do wykonywania praktycznego zawodu lekarskiego, że konieczne jest, aby dysponował takim usposobieniem, które opiera się na przymiotach duszy, właśnie na cnotach moralnych. Ten bowiem, kto szuka sławy medycznej, winien najpierw dowieść, że owe przymioty są jego własnością. Są one - to niezwykle istotna uwaga Szczuckiego - jego własnym dziełem: zanim więc będzie poznawać innych ludzi, powinien najpierw poznać samego siebie. Poznać przeto winien także własne słabości i wady, aby je przemóc i obrócić w cnotę - a to

${ }^{37}$ W. Szczucki, Krótki zbiór zasad medycyny praktyczney, Warszawa 1818, s. 2.

${ }^{38}$ Tamże, s. 6.

39 Tamże, s. 9.

40 A. Wolff, Rys sztuki leczenia, czyli terapia ogólna i szczególna, cz. I, Kraków 1816, s. 7.

${ }^{41}$ Tamże, s. 206. 
wymaga nieustannego ćwiczenia się w czynieniu dobra. Nie pomoże żmudne sporządzanie szczegółowych reguł ani przymus ich stosowania, albowiem wypełnienie obowiązków moralnych względem innych zakłada wypełnienie ich wobec siebie: „Dokładnych więc i na każdy przypadek oznaczonych przepisów, udzielić w tej mierze jest prawie niepodobna jest przymusić kogo, aby nietylko wbrew moralności niepostępował, lecz aby istotnie sam moralnie myślał" ${ }^{42}$. Tym różni się kształcenie cnót, które czyni rzeczywiste posłannictwo lekarskie, od narzuconego rygoryzmu na tych, którzy nadal swoje wady pielęgnują i z tego powodu nie będą potrafili ulżyć cierpiącym, bo takie jest - jak podaje Hufeland, na którego również powołuje się Szczucki pierwsze źródło sztuki leczenia, która wymaga od lekarza, aby spełnił fundamentalną zasadę lekarskiego postępowania: „Żyć dla innych, nie dla siebie, jest istotą jego zawodu"43. Jeśli temu nie będzie mógł sprostać, jeśli nie pogodzi się z tym, że „lekarz ani o zbieraniu majątku, ani o zaszczytach myśleć niepowinien" ${ }^{44}$, niech o przynależność do stanu lekarskiego nie zabiega. Lekarz bowiem musi czynić dobro z przekonania, niesiony pobudką, a zatem motywowany do sprawowania opieki nad chorym - żaden przepis, regulacja nie zastąpi intencji szlachetnej: „dobry uczynek traci swą wartość, jeżeli niepochodzi z przekonania" 45 .

Do cnót najważniejszych, które już u młodzieży winny być kształcone, a które w konieczny sposób muszą pozostać w dyspozycji lekarza, zalicza Szczucki: ludzkość, w tym bezinteresowność i życzliwość, dobroczynność, litość, łagodność, jak i pobłażliwość, wyrozumiałość, cierpliwość, spokojność umysłu, czystość obyczajów i nieskażony charakter duszy oraz pobożność. Tą pierwszą, naczelną cnotą jest ludzkość bezinteresowna, która pozwala odczuwać stan cierpiącego człowieka i umożliwia okazanie mu pragnienia lekarza przywrócenia choremu zdrowia. Ludzkość jest źródłem zaufania w lekarza i - co nie mniej ważne - budzi w pacjencie nadzieję. Określa ją Szczucki w niezwykle zwięzły sposób: „Ludzkość prawdziwa, czyni lekarza życzliwym przyjacielem wszystkich współbliźnich, dla których w ogóle poświęcać się winien" ${ }^{46}$. Ma ona charakter bezwarunkowy i powszechny, zapewne dlatego, że jej udziałem jest miłość bliźniego i miłosierdzie jemu okazywane, które zasięgiem swoim obejmowało w religii chrześcijańskiej

${ }^{42}$ W. Szczucki, Propedeutyka do nauk..., dz. cyt., s. 200.

${ }^{43}$ C.W. Hufeland, dz. cyt., S. 7.

${ }^{44}$ W. Szczucki, Propedeutyka do nauk..., dz. cyt., s. 168.

${ }^{45}$ Tamże, s. 194.

${ }^{46}$ Tamże, s. 201. 
wszystkich, bo służy ono „wszystkim ludziom ze względu na szlachetną, uczynną naturę swego powołania, bez różnicy narodowości czy wyznania. Bowiem miłosierny nie rozróżnia ludzi złych od dobrych, wdzięcznych od niewdzięcznych" ${ }^{47}$.

Z ludzkości wypływają więc takie przymioty moralne, jak dobroczynność, owo pragnienie bycia uczynnym, litość, jak również sprawiedliwość $\mathrm{w}$ równym traktowaniu chorych niezależnie od ich statusu majątkowego. Cnoty te uzdalniają lekarza, czyniąc go zdolnym do niesienia pomocy cierpiącym, ale też chronią go przed wadami, choćby przed pazernością, której westchnienie chorego, będące oznaką wdzięczności, nie wystarcza: „Kto z przeznaczenia swego winien przynosić ulgę i pociechę, czyliż godzi się, aby ten sam z drugiej strony jeszcze zadawał chłostę człowiekowi, który cierpiąc na zdrowiu, a $\mathrm{z}$ tego powodu znajdując się $\mathrm{w}$ niemożności zarabiania, cierpi także częstokroć uszczerbek zwykłych dochodów"48.

Z ludzkości wynika jeszcze jedna cnota, a mianowicie łagodność $\mathrm{w}$ postępowaniu $\mathrm{z}$ chorym, która polega na osłodzeniu choremu owego przykrego stanu, w jakim się znajduje: „Łagodność w obchodzeniu się, na tem szczególniej zawisła, aby lekarz miał bydź pobłażającym i wyrozumiałym na ułomności ludzkie" ${ }^{49}$ - jest ona warunkiem skutecznego udzielania pomocy. Srogość zaś wobec chorego jest naganna nawet wtedy, gdy chory nie stosuje się do lekarskich zaleceń. Wtedy bowiem lekarz powinien, kierując się pobłażliwością i wyrozumiałością, czyli unoszeniem wad lub słabości ludzkich, tłumaczyć szkodliwość takiego postępowania z umiarkowaniem, uwzględniając stan chorego, jego wrażliwość i wychowanie. Dlatego konieczna staje się cierpliwość w leczeniu chorego.

Cierpienie chorego, jego umieranie oraz postawy jego bliskich wpływają również na samego lekarza. Wzruszenia, które są jego udziałem, mogą negatywnie wpływać tak na emocje lekarza, jak i jego umysł. Bycie świadkiem cierpień; niemożność zaradzenia i pomocy, gdy sztuka lekarska ujawnia swoje granice; trud i wysiłek - wszystko to może zachwiać spokojem lekarza, a spokój ów jest konieczny, ponieważ jest warunkiem właściwego obchodzenia się z chorym. Szczucki zatem uznaje spokojność umysłu za cnotę, która polega na ciągłym poskramianiu „wszelkich namiętności zbytecznych; na czem zasadza

${ }^{47}$ B. Urbanek, Pojęcie miłosierdzia w opiece nad chorym do XIX wieku, „Medycyna Nowożytna" 1999, nr 6, z. 1, s. 71.

${ }^{48}$ W. Szczucki, Propedeutyka do nauk..., dz. cyt., s. 185.

${ }^{49}$ Tamże, s. 194. 
się moc: panowania nad sobą"50, a która nie ma nic wspólnego z obojętnością będącą jedynie wyrazem nieludzkości. Spokojność umysłu lekarza chroni także chorego przed tymi wzruszeniami, które moga cierpiącemu sprawić przykrość. Łatwiej lekarzowi będzie podołać tym wymaganiom i oczekiwaniom, jeśli zachowa czystość obyczajów i nieskażony charakter duszy. Szczególnie wtedy są one potrzebne, gdy lekarz wkracza w sferę tego, co dla chorego jest wstydliwe. Dlatego lekarz „powinien bydź wzorem dobrych obyczajów, i zachowywać przepisy umiarkowania i skromności, któraby mu w każdym przypadku czyniła zaletę. $Z$ tego powodu wymagamy od lekarza, aby także umiarkowanym był w mówieniu: umieć milczeć, gdzie wypada, cnotą a razem istotnym jego jest obowiązkiem; umieć mówić, jak należy, tej samej cnoty jest udziałem"51.

Główną cnotą jest dla Szczuckiego pobożność (religia), a to dlatego, wyjaśnia, że to właśnie nauki lekarskie ukazują w cudowności organizmu ludzkiego wielkość Boga. Religia bowiem ,jest najprostszą drogą do wykonywania cnoty, na której jak każdy człowiek, tak też bardziej jeszcze, powołanie swoje dostatecznie ugruntować powinien"52. Jakkolwiek interpretując to przekonanie Szczuckiego, z pewnością dwie przesłanki są oczywiste: po pierwsze, powołanie lekarza, tak szlachetne i szczytne, ludzkie jednocześnie, choć w sobie zawierające wszystko to, co najlepsze w człowieku, wymaga podniesienia do sfery sacrum; po drugie, religia przynosi pociechę cierpiącym i umierającym, uczy dobrodziejstwa, miłosierdzia i pokory, wspierając lekarza w jego obowiązkach.

Szczucki ma świadomość tego, że kreśląc ów katalog cnót, unosi moralnie lekarza, jednak zaznacza, że byłoby jednocześnie pochlebianiem sobie, gdyby ulec przeświadczeniu, że ze sposobności wykonywania zawodu lekarza posiada on wszystkie te cnoty. Inwentarz ich jest, w gruncie rzeczy, skonkretyzowaniem moralnego ideału lekarza. To punkt odniesienia, z którym należy się zmierzyć, sięgając po przywileje i obowiązki lekarskie: ,jeżeli komu na głównych przymiotach wcale zbywa, i kto w tej mierze więcej ma skłonności do uchybienia, jak do zachowania przepisów; temu życzymy, aby raczej odstąpił lekarskiego zawodu, gdzie żadna namiętność ukryć się długo niepotrafi, a skutki jakie wynikają w rozmaitym względzie zwykły bydź szkodliwemi”53. Zawód lekarski obnaża bowiem ludzkie wady, słabości czy

\footnotetext{
50 Tamże, s. 195-196.

51 Tamże, s. 197.

52 Tamże, s. 198.

53 Tamże, s. 200.
} 
niepożądane skłonności. Wykonując więc ów zawód, nikt nie ukryje siebie, jeśli tej szlachetności moralnej nie starcza: nie tylko słowa, ale spojrzenie bądź westchnienie chorego, najdrobniejszy gest zawsze to zdradzi.

Powołanie lekarza jest wyzwaniem trudnym, jak pisze Ludwik Bierkowski, ponieważ wynikające $\mathrm{z}$ niego obowiązki wypełniać musi lekarz należycie i sumiennie, do czego konieczne jest posiadanie umiejętności i wiedzy lekarskiej w praktycznym wykonywaniu tej sztuki, czynić to z utalentowaniem. To sztuka najtrudniejsza ze wszystkich, bo za przedmiot mająca żywy organizm, który wiele tajników jeszcze ukrywa; bo w jej wykonywaniu czas odgrywa istotną rolę, szczególnie wtedy, gdy nagli; bo popełnione błędy w jej wykonywaniu są nie do naprawienia, a gdy zdrowie zostaje $\mathrm{z}$ ich powodów utracone, przywrócić już jego nie można. Uprawianie sztuki lekarskiej dokonuje się w obecności tej rzeczywistości, która objawia się „zmysłom lekarza ciągłym prawie widokiem cierpienia, niepokoju, boleści i obawy, trwogi, lub rozpaczy" ${ }^{4}$. Dlatego będąc pod tym zgoła niekorzystnym wpływem moralnym, potrzebuje lekarz mocy duszy, owej spokojności umysłu, doświadczenia i wprawy wręcz artystycznej. Celem usiłowań lekarza jest zdrowie i życie ludzkie, a ochronić je może wtedy, gdy spełni on to wymaganie: należy być ,uzdatnionym lekarzem, aby nie łudzić i nie zwodzić ani samego siebie, ani drugich współbliźnich, żądających od nas w chwilach cierpienia trwogi lub rozpaczy, stosownej rady i pomocy" 55 .

Leon Chodakowski w artykule Obowiązi lekarza (1850), podążając za Hufelandem, odmalowuje oblicze lekarza-dobroczyńcy i wprost formułuje zestaw przymiotów moralnych, które to dobroczynienie warunkują: „lekarz może stać się wielkim dla swoich chorych dobroczyńcą, skoro nie tylko z życzliwością udziela pomocy, ale z prawdziwą delikatnością zwraca wzgląd na ich ekonomiczne przykre położenie" ${ }^{56}$. Aby to czynić, winien lekarz dysponować usilną i sumienną troskliwością, nieskazitelną prawością, umiarkowaniem, prawym prowadzeniem się, skromnością, mądrością oraz przytomnością umysłu w sądach i bacznością w wyborze towarzystwa. Natomiast Józef Jakubowski w rozprawie $O$ przeszkodach w leczeniu (1852) wymienia następujące przymioty lekarza, przyznając jednocześnie, że natura szczodrze nie obdziela nimi - nie tylko zresztą lekarzy: „moc

\footnotetext{
${ }^{54}$ L. Bierkowski, dz. cyt., s. XIX.

55 Tamże, s. LIX-LX.

${ }^{56}$ L. Chodakowski, O obowiazkach lekarza (z Hufelanda), „Tygodnik Lekarski” 1850, nr 3, s. 18.
} 
charakteru, sumienność, wygórowane uczucie ludzkości, wyrzeczenie się wszelkich niegodnych błyskotek i zaszczytów po największej części chwilowych i rychło znikających, szlachetna łatwość przebaczenia usterków chorego, dążenie do prawdy, udzielanie następcom przestróg wyznaniem otwartem własnych popełnionych błędów itp. przymioty zdobić powinny lekarza i zawsze stać mu przed oczyma"57. Dzięki tym przymiotom i zdolnościom buduje dobrą opinię o sobie wśród chorych. Niszczy tę natomiast opinię, a jednocześnie jest sprzeczne z powołaniem lekarskim, oddawanie się szulerstwu, bo chorzy stronią od niego; pijaństwu, bo ono rozum mu odejmuje; rozpuście, bo pozbawia prawości i charakteru. Nie kieruje się więc lekarz, jak podkreśla Ferdynand Dworzaczek, ani zyskiem, ani ambicją, „,bo wie dobrze, że ani zaszczytów, ani majątku na tej drodze szukać nie należy" ${ }^{58}$, ponieważ „Nagroda, której szuka i pragnie, jest szacunek i miłość tych, którym służy"59.

Dlatego sztuka lekarska jest ze wszystkich sztuk najtrudniejszą, a bodaj właśnie z tego powodu można, przekonuje Adam Raciborski, „powiedzieć o medycynie, że jest jak te błogosławione ziemie, na których wszystkie korzystne rośliny jak najpiękniej się przyjmują i na użytek ludzkości obracają" ${ }^{0}$. Czerpać winna zatem ze wszelkich nauk i sztuk to, co ją wspomoże w ochronie zdrowia i życia ludzkiego. Postęp bowiem w naukach i technice ma zbawienny wpływ na leczenie, aczkolwiek bywa, że na jego przeszkodzie stoją również lekarze, oddając się spekulacjom choćby w postaci homeopatii czy magnetyzmu. Nawołuje więc Raciborski do tego, aby tę maskę szarlatanerii z nich zrzucać, ponieważ są to ci, którzy „nigdy sumiennie nie pracowali, aby się obeznać jak należy ze sztuką lekarską"'61; którzy pod roztoczonym przez siebie urokiem szarlatanerii skrywają własny interes w tym, ,aby zaprzeczać postępu w medycynie”62. Bierkowski tę szarlatanerię biorącą się ze zwykłego oszustwa upatruje w homeopatii, jak również w hydropatii czy tajemnych pigułkach i proszkach. Urąga to sztuce lekarskiej, tym bardziej że oddawanie się tym praktykom jest

57 J. Jakubowski, O przeszkodach $w$ leczeniu. Rozprawa odczytana na publicznem posiedzeniu Towarzystwa Naukowego Krakowskiego w dniu 8 Marca 1852, Kraków 1852, s. 52.

${ }^{58}$ F. Dworzaczek, Rzecz dotyczaca filozofii medycyny, „Pamiętnik Towarzystwa Lekarskiego Warszawskiego" 1857, nr 13(37), s. 90.

${ }^{59}$ Tamże.

${ }^{60}$ A. Raciborski, Mowa o styczności medycyny z innemi naukami, sztukami pięknemi i literatura, Paryż 1858, s. 5.

${ }_{61}$ Tamże, s. 23.

${ }^{62}$ Tamże. 
często szkodliwe dla zdrowia bądź zagrażające nazbyt często życiu człowieka. Homeopatia dla myślącego lekarza jest „nic nieznaczącym zerem”"3 , a myśl o rozcieńczaniu jakichkolwiek środków w tak niepojętych, wręcz absurdalnych, dawkach „Jest to coś więcej aniżeli urągać się z rozumu ludzkiego chcąc taką myśl urzeczywistnić, jest to po prostu najwyższe oszustwo, jakie się tylko do umiejętności i sztuki lekarskiej wkraść mogło"64. Nie tylko jednak ta moralna wadliwość, jaką jest oszustwo, ujawniała się w praktykach homeopatycznych czy hydropatycznych, w magnetyzmie czy czymkolwiek innym, co z nauką nie po drodze miało, ale także w samych postawach lekarzy, gdy chorobę i pacjenta pragnęli opanować łaciną, co Raciborski nazywa pedantyzmem. Dostrzegając pozytywny wpływ krytyki lekarzy, który miał miejsce w niejednej sztuce Moliera, a przede wszystkim w Chorym z urojenia, pisze: „Nie ma jednak wątpliwości ta sztuka przyczyniła się najwięcej do zrzucenia maski, która śmieszną raczej jak poważną powierzchnością, grubą nieumiejętność najczęściej pokrywała" ${ }^{65}$. Ta krytyka pedantyzmu „odjęła na zawsze lekarzom, przynajmniej we Francyi, chęć popisywania się łaciną przed chorymi i strąciła mistyczną zasłonę"66.

Choć tematyka cnót moralnych jako przedmiot odrębnej refleksji pojawia się niezbyt często $\mathrm{w}$ tekstach lekarskich odwołujących się do filozofii moralnej, nie oznacza to jednak, że odgrywała ona poślednią rolę. Wręcz przeciwnie, czego świadectwem są wszelakie mowy wygłaszane na cześć lekarzy, które wprost oddają moralny kanon rozpisujący zalety dobrego lekarza. Odczytać ów kanon można w pochwale Walentego Gagatkiewicza napisanej przez Franciszka Lafontaine'a: „Dobroć i wielkość duszy były zawsze najznakomitszym Gagatkiewicza moralnym udziałem. Dowodem tego jest ta czuła litość, która w wydarzonych przypadkach, dzielnie i czynnie serce jego wzruszała. Nędza, ubóstwo i cierpienia współbliźnich prędko i w najwyższym stopniu przejmowały duszę jego, a potem żywem uczuciu, natychmiast śpieszył im na ratunek" "67. Uwzględniając nadto sposób Gagatkiewicza, w jaki udzielał porad lekarskich, Lafontaine przypisuje mu również cnotę posłannictwa,

\footnotetext{
${ }^{63}$ L. Bierkowski, dz. cyt., s. XXX.

${ }^{64}$ Tamże, s. XXXII-XXXIII.

65 A. Raciborski, Mowa o styczności medycyny..., dz. cyt., s. 28.

${ }^{66}$ Tamże, s. 29.

${ }^{67}$ F.L. Lafontaine, Mowa na pochwałe ś. p. wielmożnego jegomości pana Walentego Gagatkiewicza konsyliarza nadwornego ś.p. Stanisława Augusta króla polskiego, doktora medycyny, tudzież członka Towarzystwa Przyiaciót Nauk $w$ Warszawie, czytana na publiczném posiedzeniu tegoż Towarzystwa dnia 15 maja 1805 roku przez Leopolda de Lafontaine, Warszawa 1805, s. 8.
} 
ofiarności i miłosierdzia. Ten ostatni charakteryzował się zaś, jak pisze Michał Bergonzoni, współodczuwaniem i współczuciem kierowanym do chorych: „Taką był zawsze czułością przejęty, gdy chorych w boleściach ratował, iż prawie zdawało się, że z nimi dzieli cierpienie, co jednak bynajmniej nie przeszkadzało do jego stałości w działaniu; słowem, taki był Lafonten względem swego stanu, jakimi wszyscy lekarze bydź powinni”“68. Przede wszystkim z nieoszacowaną dobrocią duszy, tkliwą czułością serca i stałością umysłu ${ }^{69}$.

W Kursie propedeutyki lekarskiej (1876) Henryk Łuczkiewicz również dostrzega, zgodnie zresztą z przedmiotem nauki obyczajowej, wady lekarskiego charakteru, do których zalicza przede wszystkim: zawiść, wywyższanie się, szarlatanerię, a nawet skłonność do intryg. Twierdzi jednocześnie, że „Tłem wad pomienionych, z których wyradzają się postępki niegodne ludzi naukowych, a nawet istne występki przeciwko swemu powołaniu i nauce, której głoszą się kapłanami, bywa próżność, zarozumiałość, żądza zysków i niezrozumienie godności swego zawodu"70. A to powołanie w zawodzie lekarskim Łuczkiewicz odmalowuje wręcz poetycko, pisząc, że jest ono zadaniem pięknym, szczytnym, szlachetnym, a nawet przyjemnym, ponieważ lekarz w organizacji życia dostrzega głęboką mądrość i niezłomność praw oraz kunsztowność świata organicznego. Rozczytywanie się w tej księdze życia ,jest zaprawdę zajęciem rozkosznem dla wyższego umysłu i dziwnie uszlachetniającym"71, gdyż niesienie pomocy jest źródłem zadowolenia z poczucia i uznania dobrych uczynków. Dzięki nim właśnie zyskuje lekarz miano dobroczyńcy, pocieszyciela, opiekuna biednych i cierpiących. Nie może więc dziwić, że Łuczkiewicz do przymiotów moralnych lekarza przywiązuje „wartość pierwszorzędną tak, że nieposiadający ich traci w oczach naszych charakter prawdziwego lekarza i zniża się do stopnia mniej lub więcej zdolnego, fachowego procederzysty"72.

${ }^{68}$ A. Bergonzoni, Rzecz czytana o Leopoldzie Lafontenie przez Michała Bergonzoniego med. d. b. Proto-Medyka, Inspektora Jeneralnego stużby zdrowia Wgo Xięstwa Warszawskiego, człon: czynnego Towarzystwa Królewskiego Warszawskiego Przyjaciót Nauk, dnia 30. kwietnia roku 1814 na publicznem posiedzeniu tegoż Towarzystwa, Warszawa 1814, s. 21.

${ }^{69}$ H. Dzierkowski, Biografia życia ś.p. Fryderyka Spaetha assessora Rady Ogólnej i członka Kommissyi Ogólnej i członka Kommissyi Examinacyiney Lekarskiey Xięstwa Warszawskiego w dowód kolegowania, chołdu i przyiaźni [...], Warszawa 1813.

${ }^{70} \mathrm{H}$. Łuczkiewicz, Kurs propedeutyki lekarskiej, czyli wstęp do nauki medycyny, Warszawa 1876, s. 44.

${ }^{71}$ Tamże, s. 37.

${ }^{72}$ Tamże, s. 214. 
Katalog przymiotów moralnych, dzięki którym lekarz może sprostać swemu powołaniu, tworzą według Łuczkiewicza: współczucie, cierpliwość, bezinteresowność oraz taktowność. Może lekarz nimi dysponować jedynie wtedy, gdy jego życie jest cnotliwe, obyczajne i skromne. Cnota ma wpływ dobroczynny, czystość obyczajów jest zaś gwarancją sumiennego spełniania obowiązków, a za sprawą skromności ustrzec się można przed wszelkimi pokusami, z których główne dotyczą wykorzystania relacji z pacjentem w celu innym niż terapeutyczny. Tym jednak, co winno cechować lekarza, jest współczucie dla cierpienia - to perła cnót, która objawia się natychmiast i ma charakter czynny: współczucie okazywane przez lekarza „to czyn równie odważny, jak wojownika na placu boju - jego litość, to pomoc niesiona choremu w chwili, kiedy nierzadko opuszczają go znajomi, przyjaciele, a czasem krewni i najbliżsi"73. Współczucie wyraża się w gorliwości wypełniania obowiązków, w staranności w sprawowaniu opieki, $\mathrm{w}$ pragnieniu niesienia pomocy, $\mathrm{w}$ wyrozumiałości dla ludzkich słabości oraz w pobłażliwości - „Lekarz z tymi przymiotami, przynosi nie tylko pomoc w chorobie, ale napawając pacjenta ufnością w swój charakter, łagodzi obawę jego o życie, rozbudza wiarę w słowa i postępowanie swoje, uspakaja otaczających, jednym słowem osładza niedolę, godzi z losem" ${ }^{\prime 4}$. Cierpliwość natomiast winna być okazywana przede wszystkim w badaniu i leczeniu chorych, a wszelkie przykrości, jakie mogą płynąć ze strony pacjentów, należy umieć znosić ze spokojem i pokorną wyrozumiałością. Z roli lekarza wynika także bezinteresowność, zdolność do filantropii, która nie jest nakazem moralnym, ale bodaj rezultatem sprawiedliwego traktowania chorych. Lekarz zatem, podkreśla autor Kursu propedeutyki lekarskiej, nie powinien się martwić o swe dochody, jeśli wykaże starania, aby pacjenci obdarzali go większym szacunkiem. Temu też służyć ma taktowne postępowanie: „Wobec chorego lekarz musi być spokojnym, uprzejmym, rozważnym, umiarkowanym w słowach, stanowczym i arcy przyzwoitym"75. Stronić winien od lekkomyślności, trzpiotostwa, od nadmiernej żartobliwości (w tym płytkiego dowcipu), przesady, fanfaronady i jakiegokolwiek dziwactwa, ponieważ te przywary szkodzą jego wizerunkowi, podważają zaufanie i - ostatecznie - odbierają mu szacunek u chorych.

Jest jednak zastanawiające, że w drugiej połowie XIX w., wieku zdominowanym przez pozytywistyczne postulaty uprawiania nauki,

73 Tamże, s. 217.

${ }^{74}$ Tamże, s. 218.

75 Tamże, s. 224. 
w tym również etyki jako etologii (etyki opisowej), silnie inspirowanej ewolucjonizmem, względnie utylitaryzmem, pomimo odrzucenia tradycyjnej filozofii moralnej (jako etyki normatywnej), pozostała ona trwałym elementem refleksji nad moralnymi przymiotami lekarza. Jej najpełniejszy wyraz odnaleźć można w Myślach i aforyzmach Władysława Biegańskiego, który przywracając obecność i ważność refleksji nad cnotami, dokonał wręcz przełomu teoretycznego, opowiadając się przeciwko dominującym postaciom pozytywistycznej myśli etycznej. Przełom ów polegał także na zakwestionowaniu już zaistniałego monopolu korporacji lekarskiej na uzasadnienie i formułowanie powinności moralnych lekarza. Biegański podważa również przekonanie przyjmujące, że cnót, ideałów lekarskich nabywa się dzięki ich poznaniu, bo ono nie czyni lekarza ani moralnym, ani zdolnym do sprawowania opieki nad chorym: „Chcąc wpłynąć na postępki ludzi, należy poruszyć ich serca, ich przekonania moralne, a tego nigdy nie dokonasz przez rozumowanie"76. Jednym słowem - jakiekolwiek normatywy deontologiczne pozostaną martwe, jeśli nie wypływają z uczuć lekarzy. Te uczucia, które podlegają rozwojowi i kształtowaniu przez ideały, są treścią cnót. Jako że wszelkie czyny z uczuć wynikają, dlatego, pisze Biegański, „Poznanie obowiązku nie czyni człowieka lepszym, nie wpływa na jego czyny. Obowiązku nie można nauczać jak katechizmu, z książki; obowiązek trzeba wpajać, trzeba wszczepiać w duszę człowieka, poruszając odpowiednie uczucia"77.

W Myślach i aforyzmach, rozpisując ideał filantropii jako ideał naczelny, fundamentalny zawodu lekarskiego, Biegański uzasadnia go cnotami filozofii moralnej: miłością (ludzkością), współczuciem, pragnieniem niesienia pomocy i pragnieniem bycia dobroczynnym. Osadzony na tych cnotach ideał filantropii uwrażliwia bowiem na ludzkie cierpienie, skłania do cierpliwości i wyrozumiałości, którym to zaletom moralnym towarzyszyć powinny kolejne: bezinteresowność, poświęcenie, panowanie nad sobą, stanowczość i sumienność (rzetelność) lekarza, jego własna godność wyrażająca się w zgodności myśli i czynów. Cnoty te wypływają więc z ideałów i są trwałymi własnościami usposobienia moralnego dobrego lekarza. Świadomość tego, że cnoty czynią lekarza zdolnym do pełnienia obowiązków, wypowiedział dobitnie Henryk Struve po lekturze Myśli i aforyzmów: „czyż można pominąć w rozleglejszym wykładzie etyki zawodu lekarskiego rozbiór i charakterystykę wydatnych cnót lekarza, z których każda określa

\footnotetext{
${ }^{76}$ W. Biegański, Myśli i aforyzmy o etyce lekarskiej, Częstochowa 1925, s. 44.
}

77 Tamże, s. 65. 
prawidłowe, a więc sumienne i taktowne spełnianie różnorodnych obowiązków zawodu?"78.

\section{Zakończenie}

Regulacje deontologiczne, które pojawiają się jako uchwały towarzystw lekarskich na przełomie XIX i XX w., przemieszczają problematykę moralnego usposobienia lekarza na pole szczegółowych wymagań dotyczących korporacyjnych relacji między lekarzami. Potrzeba unifikacji postaw lekarzy w oparciu o normy deontologiczne wytworzyła przeświadczenie, że wypełnienie definiowanych tam obowiązków jest wystarczającym warunkiem bycia dobrym lekarzem. Cnoty moralne stały się czymś zgoła jedynie zalecanym, sprowadzanym wręcz do etykiety, uzasadnionym przez normy deontologiczne, i były o tyle obowiązujące, o ile służyły zachowaniu godności zawodowej. Nie można się zatem dziwić krytyce tak rozumianej etyki lekarskiej przez Szczęsnego Bronowskiego, poddającego na łamach „Nowin lekarskich" w wątpliwość istnienie etyki zawodowej, do której odwołują się głównie ci, którym najbardziej leży na sercu „interes osobisty i stanowy znakomicie nieraz ukrywany" ${ }^{2}$. Bronowski jednoznacznie apeluje o takie rozumienie etyki lekarskiej, która „będzie uważała niewątpliwie za najważniejsze stosunek lekarzy do publiczności, potrzebującej pomocy lekarskiej”80, jako etyki ogólnoludzkiej dążącej do powszechnego dobra. Bronowski piętnuje egoizm lekarzy, interesowność, brak posłannictwa i nieczułość, upominając, że „Chory w lekarzu chce widzieć nie tylko człowieka zdolnego mu zapewnić zdrowie, ale i zarazem przyjaznego sobie, szczerze mu oddanego" ${ }^{81}$. Formułuje jednocześnie apel i przestrogę: „Dochodzimy więc do tego niezbitego przeświadczenia, że bez pierwiastka filantropijnego, bez szczerego i bezinteresownego współczucia dla cierpiących, nasza służba nie ostoi i stanie się rzemiosłem również dobrem, jak wiele innych z prawem urządzania strejków, współzawodnictwa zarobkowego itd., ale bez praw na szczególny szacunek i uznanie, często w rozterce z własnymi sumieniem, z otoczeniem i kolegami" "22. Zygmunt Kramsztyk podziela również to przekonanie, że medycyna jest rzemiosłem,

${ }^{78}$ H. Struve, O etyce zawodu lekarskiego z powodu ksiażki W. Biegańskiego, „Krytyka lekarska" 1900, nr 1(4), s. 4.

79 S. Bronowski, Etyka lekarska $i$ wyjawienie prawdy, „Nowiny lekarskie” 1900, nr 14(12), s. 494.

${ }^{80}$ Tamże, s. 496.

${ }^{81}$ Tamże.

${ }^{82}$ Tamże. 
lecz „Jest to rzemiosło najwyższe, bo organizm ludzki, najdroższa własność człowieka, sam człowiek jest materiałem, na który lekarz swą czynność wywiera, bo o największy skarb człowieka, o życie i zdrowie, idzie w tej czynności" ${ }^{83}$. Apeluje przeto Kramsztyk, aby ten aspekt medycyny, który dotyczy ludzkiego cierpienia i nieszczęścia, zasługiwał na największe uwzględnienie ${ }^{84}$.

Nie milkną jednak w kulturze medycznej refleksje nad cnotami moralnymi. To usposobienie charakteru i jednocześnie uzdolnienie moralne do wykonywania zawodu lekarskiego jest tematem rozważań w wielu tekstach lekarskich, które ukazały się po Propedeutyce Henryka Łuczkiewicza. Matrycą refleksji stał się bez wątpienia rejestr cnót lekarza Wincentego Szczuckiego. Cytaty, nawiązania i echa tej filozofii moralnej odnaleźć można u Adama Wrzoska (Propedeutyka lekarska, 1913), u Heliodora Święcickiego (O estetyce w medycynie, 1911), u Teodora Heimana (Etyka lekarska, 1917), również u Henryka Nusbauma (Zarys etyki medycznej, 1932), jak i u Kazimierza Filipa Wizego (Pięć cnót kardynalnych lekarza, 1935). Jednakże rehabilitacja tej filozofii moralnej nastąpiła w myśli Władysława Biegańskiego, pierwszego w Europie XX-wiecznej antynaturalistycznego i antydeontologicznego przełomu ${ }^{85}$. Myśli i aforyzmy (1899) oraz Etyka ogólna (1918) Biegańskiego podejmują problematykę cnót jako fundamentalną dla myśli etycznej i etyczno-lekarskiej.

\section{Bibliografia}

Barański J., Etyka Władysława Biegańskiego i jej normatywne oblicze, [w:] E. Starzyńska-Kościuszko (red.), Wartości i wartościowanie we współczesnej humanistyce. Perspektywa filozoficzna, Olsztyn 2017.

Bergonzoni A., Lublin podług ustaw medyki uważany w jednej dyssertacyi, Lublin 1792.

Bergonzoni A., Rzecz czytana o Leopoldzie Lafontenie przez Michata Bergonzoniego med. d. b. Proto-Medyka, Inspektora Jeneralnego służby zdrowia Wgo Xięstwa Warszawskiego, człon: czynnego Towarzystwa Królewskiego Warszawskiego Przyjaciół Nauk, dnia

${ }^{83}$ Z. Kramsztyk, Czy medycyna jest nauka, czy sztuka, [w:] Z. Kramsztyk, Szkice krytyczne z zakresu medycyny, Warszawa 1899, s. 121.

${ }^{84}$ Tamże.

85 J. Barański, Etyka Władysława Biegańskiego i jej normatywne oblicze, [w:] E. Starzyńska-Kościuszko (red.), Wartości $i$ wartościowanie we wspótczesnej humanistyce. Perspektywa filozoficzna, Olsztyn 2017, s. 131-144. 
30. kwietnia roku 1814 na publicznem posiedzeniu tegoż Towarzystwa, Warszawa 1814.

Biegański W., Myśli i aforyzmy o etyce lekarskiej, Częstochowa 1925.

Bieliński J., Stan nauk lekarskich za czasów Akademii Medyko-Chirurgicznej Wileńskiej, Warszawa 1888.

Bierkowski L., Wstęp do anatomii ciała ludzkiego, Kraków 1850.

Borówka J., Polska etyka lekarska w ujęciu dziejowym. Studium filozoficzno-historyczne, Torun 2012.

Bronowski S., Etyka lekarska i wyjawienie prawdy, „Nowiny lekarskie" 1900, nr 14(12).

Chodakowski L., O obowiazkach lekarza (z Hufelanda), „Tygodnik Lekarski” 1850, nr 3.

Czerwiakowski R.J., Dyssertacya o szlachetności i potrzebie Chirurgii w Pożyciu Ludzkiem, W Woysku, Przy Połogach i w Nauce Lekarskiey, Warszawa 1791.

Dmochowski F.K., O cnotach towarzyskich $i$ wystepkach im przeciwnych, [w:] F.K. Dmochowski, Pisma rozmaite, t. 2, Warszawa 1826.

Dworzaczek F., Rzecz dotyczaca filozofii medycyny, „Pamiętnik Towarzystwa Lekarskiego Warszawskiego" 1857, nr 13(37).

Dzierkowski H., Biografia życia ś.p. Fryderyka Spaetha assessora Rady Ogólnej i członka Kommissyi Ogólnej i członka Kommissyi Examinacyiney Lekarskiey Xięstwa Warszawskiego w dowód kolegowania, chołdu i przyiaźni [...], Warszawa 1813.

Grzelak E., Co powinno cechować chirurga według R.J. Czerwiakowskiego, „Biuletyn Wojskowej Akademii Medycznej” 1963, nr IV, z. 3-4.

Hufeland C.W., Die Verhältnisse des Arztes, „Neues Journal der praktische Arzneykunde und Wundarztneykunst" 1806, t. 16.

Jakubowski J., O przeszkodach w leczeniu. Rozprawa odczytana na publicznem posiedzeniu Towarzystwa Naukowego Krakowskiego w dniu 8 Marca 1852, Kraków 1852.

Kołłątaj H., Korrespondecya listowna z Tadeuszem Czackim, Kraków 1845.

Koncewicz L., Nauka moralna o powinnościach człowieka względem siebie samego ułożona dla użytku klass wyższych szkót wojewódzkich, Warszawa 1830.

Kramsztyk Z., Czy medycyna jest nauka, czy sztuka, [w:] Z. Kramsztyk, Szkice krytyczne z zakresu medycyny, Warszawa 1899.

Lafontaine F.L., Mowa na pochwałe ś. p. wielmożnego jegomości pana Walentego Gagatkiewicza konsyliarza nadwornego ś.p. Stanisława Augusta króla polskiego, doktora medycyny, tudzież członka 
Towarzystwa Przyiaciót Nauk w Warszawie, czytana na publiczném posiedzeniu tegoż Towarzystwa dnia 15 maja 1805 roku przez Leopolda de Lafontaine, Warszawa 1805.

Łuczkiewicz H., Kurs propedeutyki lekarskiej, czyli wstęp do nauki medycyny, Warszawa 1876.

Markiewicz A., Nauka obyczaiowa o obrzydzeniu występków, wad i przesqdów a zamiłowaniu prawdy, cnoty i przymiotów towarzyskich do ukształcenia młodzieży na dobrych ludzi, obywatelów i urzędników stosowna, Kraków 1810.

Perzyna L., Lekarz dla włościan czyli rada dla pospólstwa, w chorobach i dolegliwościach naszemu Kraiowi właściwych [...], Kalisz 1793.

Perzyna L., Nauka położna krótko zebrana. Cyrulikom położnym, iako też i Babom, czyli Kobietom, przy rozwiazywaniu rodzacych Położnic służacym dla wiadomości bardzo potrzebna, Kalisz 1790.

Potocki S.K., Pochwała Grzegorza Piramowicza, miana w Zgromadzeniu Przyjaciót Nauk, Warszawa 1802.

Raciborski A., Mowa o styczności medycyny z innemi naukami, sztukami pięknemi i literatura, Paryż 1858.

Ryszkowski F.K., Stan człowieka zdrowego naturalny, Kraków 1808.

Starowolski S., Poprawa Niektórych obyczaiow Polskich potocznych, Kraków 1625.

Struve H., O etyce zawodu lekarskiego z powodu książki W. Biegańskiego, „Krytyka lekarska” 1900, nr 1(4).

Swieżawski S., U źródeł nowożytnej etyki. Filozofia moralna w Europie XV wieku, Kraków 1987.

Szczucki W., Propedeutyka do nauk medycyny, Warszawa 1825.

Szczucki W., Krótki zbiór zasad medycyny praktyczney, Warszawa 1818.

Szumowski W., Dwa kursa propedeutyki, „Krytyka Lekarska” 1907, nr 1(11).

Szymkiewicz J., Nauka chirurgii teoryczney i praktyczney, t. 1, Wilno 1806.

Urbanek B., Pojęcie miłosierdzia w opiece nad chorym do XIX wieku, „Medycyna Nowożytna” 1999, nr 6, z. 1.

Wiszniewski M., Historya literatury polskiej, t. 3, Kraków 1841.

Wolff A., Rys sztuki leczenia, czyli terapia ogólna i szczególna, cz. I, Kraków 1816. 


\section{Summary}

\section{The virtues of a doctor in Polish medical philosophy and ethics in the nineteenth and twentieth centuries}

Moral reflection on medical behavior, particularly on moral values essential to practicing medicine, first appeared in Poland in the 18th century as part of philosophy of morality and moral science. This practical philosophy inspired by stoicism is, most of all, a catalogue of doctor's virtues and a theoretical premise for the 20-century medical ethics fully expressed by Władysław Biegański and his medical ethics. The first axiological declarations about moral duties of a doctor, which are the expression of such moral philosophy, are associated with Rafał Józef Czerwiakowski and Wincenty Szczucki. 